\title{
Gametogenic Cycle by Quantitative Statistical Analysis and the Biological Minimum Size in Protothaca (Notochione) jedoensis (Bivalvia: Veneridae) in Western Korea
}

\author{
Kwan Ha Park ${ }^{1}$, Ee-Yung Chung ${ }^{2}$, Chang Hoon Lee ${ }^{3}$, Sung Han Kim${ }^{4}$, Sung-Yeon $\mathrm{Kim}^{5}$, \\ Won-Jae $\mathrm{Seo}^{2}$ and Dong Ki Ryu ${ }^{4}$ \\ ${ }^{1}$ Department of Aquatic Life Medicine, Kunsan National University, Gunsan 573-701, Korea \\ ${ }^{2}$ Korea Marine Environment \& Ecosystem Research Institute, Dive Korea, Bucheon 420-857, Korea \\ ${ }^{3}$ Neoenbiz Co., Bucheon 420-806, Korea; \\ ${ }^{4}$ Department of Aquaculyure and Aquatic Sciences, Kunsan National University. Gunsan 573-701, Korea \\ ${ }^{5}$ Research Planing Division, National Fisheries Research and Development Institute, Busan 619-705, Korea
}

\begin{abstract}
The gametogenic cycle, the spawning season and the biological minimum sizes in female and male Protothaca (Notochione) jedoensis were investigated by quantitative statistical analysis. In females, monthly changes in the percents of the follicle areas to the ovarian tissue areas and the percents of the oocyte areas to the ovarian tissue areas increased in February and reached the maximum in April, and then gradually decreased from May to July, with the spawning peak between June and July. In males, monthly changes in the percents of the testicular tissue areas to total tissue areas and the percents of the spermatogenic stage areas to the testicular tissue areas increased in February and reached the maximum in April, and then showed a rapid decrease from May to July. From these data, it is apparent that the number of spawning seasons in female and male $P$. (N.) jedoensis occurred once a year, from May to July. Therefore, $P$. (N.) jedoensis in both sexes showed a unimodal gametogenic cycle during the year. Compared the gametogenic cycle by quantitative statistical analysis in 2007 with the previous qualitative results of this species, the results of the gametogenic cycle calculated by quantitative statistical analysis showed some differentiations in the spawning seasons evaluated by the gonad index by qualitative histological analysis. The intervals of the beginning of two spawning seasons showed one month between the results of quantitative and qualitative analyses. The biological minimum sizes (considering to $50 \%$ of group sexual maturity) in female and male clams by quantitative analysis of this species are $32.01 \mathrm{~mm}$ in shell length in females and $30.58 \mathrm{~mm}$ in males, respectively. According to the mean shell length fitted to von Bertalanffy's equation, 30.58 and $32.01 \mathrm{~mm}$ in shell length were considered to be two years old. Therefore, we assume that both sexes of this population begin reproduction from two years of age.
\end{abstract}

Keywords: Protothaca (Notochione) jedoensis, gametogenic cycle, spawning season, quantitative analysis, biological minimum size.

\section{INTRODUCTION}

The jedo venus clam, Protothaca (Notochione)

Received September 21, 2011 ; Accepted September 28, 2011

Corresponding author: Ee-Yung Chung

Tel: +82 (32) 328-5145 e-mail: eychung@kunsan.ac.kr $1225-3480 / 24403$ jedoensis (Bivalvia: Veneridae), is one of the commercially important edible clams in East Asian countries, including Korea, China, and Japan (Kwon et al., 1993; Min et al., 2004). In Korea, this clam is mainly found on the west and south coasts of Korea, inhabiting sand bottoms in the subtidal zone. As a consequence of reckless over-harvesting, the standing stock of this clam has dramatically declined in recent years (Kim et al., 2003a) and the species has been 
denoted as a target organism and fisheries resource that should be managed using a more reasonable fishing regimen (Kim et al., 2003a). For propagation and management of this species, it is important to understand the population characteristics with regard to the gametogenic cycle and age considering to the sizes at $50 \%$ of sexual maturity for propagation and living resource management.

To date, regarding the genus Protothaca. several studies have focused on aspects of reproduction, including reprodictive cycle of $P$ grata (Pizarro and Cruz, 1987), gametogenic development of $P$. asperima (Ewart et al., 1988), ultrastructure of spermatozoon of P. pectorina (Matos et al., 1997), on aspects of ecology, including effects of the tide and salinity (Era, 1985) and growth patterns within genus Protothaca (Harrington, 1987). Regarding $P$. (N.) jedoensis in Korea, there have been several studies on aspects of reproduction, including phylogenetic relationship and the reproductive cycle (Kim, 1996, 2002), sexual maturation (Kim et al., 2003), and germ cell differentiations during spermatogenesis and mature sperm (Kim et al., 2010), and on aspect of ecology, including age and growth of this specis (Kim et al., 2003b). Some authors (Ropes and Stickney, 1965; Brousseau, 1978) reported that the gametogenic cycle can be classified into the unimodal or bimodal gametogenic cycles by quantitative statistical analysis using an image analyzer system. It is known that in particular, Mya arenaria and Mercennaria mercennaria in bivalve mollusc exhibited a change from a unimodal to a bimodal cycle with decrease in latitude (Ropes and Stickney, 1965; Brousseau, 1978).

In particular, in case of Korea, the number of spawning seasons of $P$. (N.) jedoensis were once a year by qualitative histological analysis (Kim et al., 2003). However, in fact, the spawning season and the number of spawning seasons per year by qualitative histological analysis is not correct because two or more stages often occurred simultaneously within each tissue section. In this case, therefore, the staging criteria decisions were made according to conditions of majority of tissue sections by researcher's individual subjectivity. Thus, sometimes the qualitative analysis of gonad developmental stages by individual subjectivity is not correct. Therefore, because this species is commercially important and target organism for aquaculture, the period of spawning season and the number of spawning seasons needs to be studied in detail by quantitative statistical analysis for the confirmation of the unimodel or bimodel gametogenic cycles of gonads per year. Thus, despite the studies referred above, little information is available on the gametogenic cycle and the spawning season by quantitative statistical analysis, and age considering to the sizes at 50\% of sexual maturity in females and males.

Understanding the gametogenic cycle and the number of spawning seasons of this species will provide necessary information for the determination of age and recruitment period of population.

Additional information on the biological minimum size (the size at $50 \%$ of group sexual maturity) of this species would be very useful for propagation, aquaculture, and resource management. In particular, information on age considering to the size at which individuals reach $50 \%$ of sexual maturity could be useful in determining a prohibitory measure for adequate natural resource management. In the present study the gametogenic cycle and the number of spawning seasons by quantitative statistical analysis, and age considering to the size at $50 \%$ of sexual maturity in $P$. jedoensis were studied because we could not find mentioned above studies.

\section{MATERIALS AND METHODS}

\section{Sampling}

Specimens of the jedo venus, $P$. (N.) jedoensis, were collected monthly at the subtidal zones of Daecheon, Boryeong City, Korea (Fig. 1) from January to December 2007. The clams ranging from 25.3 to 62.6 $\mathrm{mm}$ in shell length were used for the present study. After the clams were transported alive to the laboratory, shell length and total weight were immediately measured.

\section{Production of histological tissue section slides of ovarian tissues}




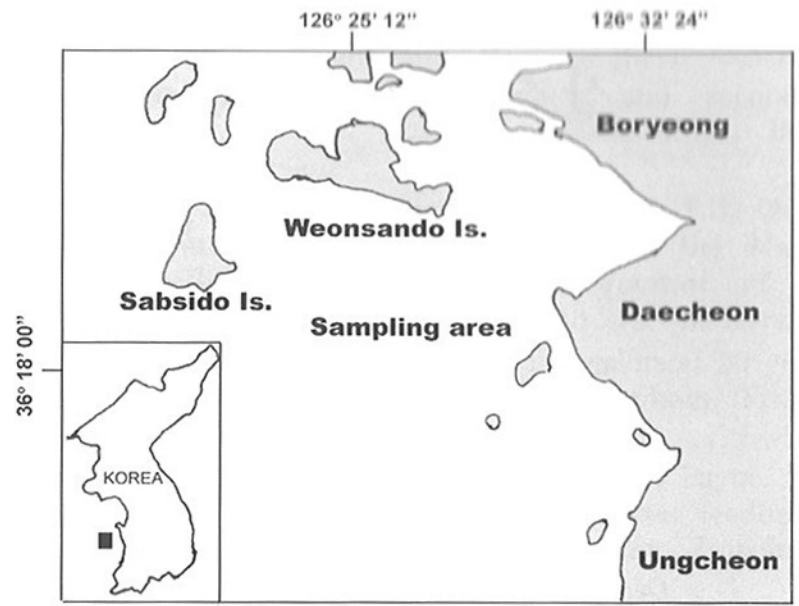

Fig. 1. Map showing the sampling station.

For light microscopic examination of histological tissue section slides by quantitative analysis, a total of 361 individuals were used for the production of histological tissue section slides of ovarian tissues. Ovarian tissues were removed from shells and preserved in Bouin's fixative for $24 \mathrm{~h}$. They were then washed with running tap water for $24 \mathrm{~h}$. then dehydrated in alcohol and embedded in paraffin molds. Embedded tissues were sectioned at 5-7 $\mu \mathrm{m}$ thickness using a rotary microtome. Sections were mounted on glass slides, stained with Hansen's hematoxylin- $0.5 \%$ eosin. After production of histological tissue section slides of ovarian tissues, they were examined using a light microscope (Zeiss Axiovert 10 microscope) for quantitative statistical analysis.

\section{Quantitative statistical analysis using an image analyzer system}

Tissue slides were observed for quantitative analysis by an image analyzer system. Slides were viewed on a stereozoom microscope (Nikon, SMZ-U) from where the images were captured by a TOSHIBA Model IK-642K CCD camera and were then viewed on a SAMSUNG color video monitor. The image analyzer (BMI plus, WINATech Co.) is capable of automatic measurement of the area and diameter of polygons encircled by the operator, counting objects that are contrasted by background color (in black and white mode), and statistical analysis of numerous characteristics of objects in the captured images. Measurements for female were carried out for areas of total tissue, the ovary, the follicle, and the oocyte, the number of the oocyte per unit area, and the diameter of each oocyte. Measurements for male were carried out for areas of total tissue, the testis, and the spermatogenic stages. Measurements on the areas of total tissue, the ovary and the testis were conducted at magnification of 7.5 at which the field area of captured image was $60 \mathrm{~mm}^{2}$, while the other measurements were done at magnification of 75 (field area: $0.524 \mathrm{~mm}^{2}$ ). 15-20 individuals per month and two fields per slides were analyzed. Areas of total tissue, the ovary, the testis, the follicle, and the oocyte were measured by manually tracking the margins of objects one by one with a pointer on the captured image. Before the measurements of the areas of the oocytes, and the diameter of the oocytes and the spermatogenic stages, captured color image was converted to a gray scale image and then to a black-and-white image with an appropriate threshold at which only the spermatogenic stages or oocytes were contrasted with black, while the other parts of the tissue were in white. Measurements on the areas of the spermatogenic stages and the oocytes, and the diameter of oocytes were carried out by the automatic procedure provided by the BMI plus software. Number of oocyte was also recorded during this automatic procedure. From the measured values of image analyses, (A) percent of field occupied by the ovary to total tissue, (B) percent of field occupied by the follicle to total tissue, (C) percent of field occupied by the follicle to the ovary, (D) percent of field occupied by the oocyte to the ovary, (E) the number of the oocyte per $\mathrm{mm}^{2}$ of the ovary, and (F) mean diameter of the oocyte in captured image were calculated for each slide of female clams. From the measured values of image analyses, (A) percent of field occupied by the testis to total tissue, and (B) percent of field occupied by the spermatogenic stages to the testis were calculated for each slides of male clams.

\section{Statistical analysis}


A one-way ANOVA (multiple comparisons by Duncan's procedure, $\alpha=0.05$ ) was applied to compare the means of monthly data. Multiple comparison by Turkey Test was used to determine significant differences in the data of two adjacent months. All statistical analyses were done using the SPSS package.

\section{Comparisons of some differences in the spawning seasons by qualitative and quantitative analyses}

Although the collection date of the specimens and the number of individuals were not same each other, in general, the gonad index and condition index by month and the spawning season of the individuals were almost same.

To estimate the spawning seasons by indirect method, we quoted the gonad index (Kim, 2002; Kim et al., 2003a) and condition index (Kim, 2002; Kin et al., 2003a,b) investigated by qualitative analysis. After final confirmation of the spawning season of this species by quantitative statistical analysis, to check some differences in the spawning seasons, we compared our results with the gonad index and condition index which studied from January to December, 1999 by Kim (2002) and Kim et al. (2003 $a, b)$.

\section{Percentages (\%) of sexual maturities by sizes using qualitative analysis of histological section slides}

For determination of the percentages (\%) of sexual maturity, a total of 291 (111 females and 117 males) clams of histological preparations $(25.3-62.6 \mathrm{~mm}$ in shell length) were examined \% of sexual maturity by shell length through histological observations, from April to September, 2007. The formular of the percentage $(\%)$ of sexual maturity is as follows: The percentage $(\%)$ of sexual maturity $=$ No. of mature individuals x $100 /$ No. of total individuals investigated.

\section{Biological minimum size (Size at the rate $(50 \%)$ of sexual maturity $\left.\left(R M_{50}\right)\right)$}

For the investigation of age composition by size, von Bertalanffy's equation used by Son et al. (1996) is as follows: $\operatorname{SLt}=\operatorname{SL8}\left(1-\mathrm{e}^{-\mathrm{k}(\mathrm{t}-\mathrm{t} 0)}\right)$.
Where, SLt: shell length $(\mathrm{mm})$ at age $\mathrm{t}$, SL8: theoretical maximum shell length, $\mathrm{k}$ : constant expressing rate of approach to SL8, t: age $t$, to: theoretical age at which $\mathrm{SL}=0 \mathrm{~mm}$, TW: total weight $(\mathrm{g})$ at age $\mathrm{t}$.

To calculate the size at the rate $(50 \%)$ of sexual maturity after fitting the rate of sexual maturity to an exponential equation, the size equivalent to the size at $50 \%$ of sexual maturity was estimated to be the sexually mature length of the population (Chung and Ryou, 2000; Kim, 2002; Kim et al., 2003a). The exponential equation of the rate of sexual maturity is as follows: $\mathrm{RM}=100 / 1+\exp ^{(\mathrm{a}-\mathrm{bx})}$, where, $\mathrm{RM}$ : rate of sexual maturity; a, b: constants, x: shell length.

\section{RESULTS}

\section{Gametogenic cycle by quantitative statistical analysis 1) Ovarian gametogenic cycle}

Female $P$. (N) jedoensis showed a unimodal gametogenic cycle (Fig. 2). As shown in Fig. 2A, the percent of field occupied by the ovary area to total tissue area began to increase in February and reached a maximum in April (70.9\%), and then gradually decreased from May (62.3\%) to July (65.6\%). During the periods of March-April and May-August, the ovarian tissue area occupied about $56 \%-71 \%$ of total tissue. The result of a one-way ANOVA (Duncan's procedure $(\mathrm{a}=0.05)$ ) during the period of January-December was 0.004. However, according to the results of multiple comparisons by Turkey Test, there were significant differences during the periods of February-March (Turkey Test, $\mathrm{p}=$ 0.017 (Fig. 2A).

In Fig. 2B, the percent of field occupied by the follicle area to total tissue area began to increase in February and reached a maximum in April (59.3\%), and then gradually decreased from May (54.5\%) to July (47.1\%). During the periods of February-April, May-July, the follicle area occupied about $40-60 \%$ of total tissue area. The result of a one-way ANOVA (Duncan's procedure $(\alpha=0.05)$ ) during the period of January-December was 0.004 . According to the results of multiple comparisons by Turkey Test, there were significant differences in the data of two adjacent 

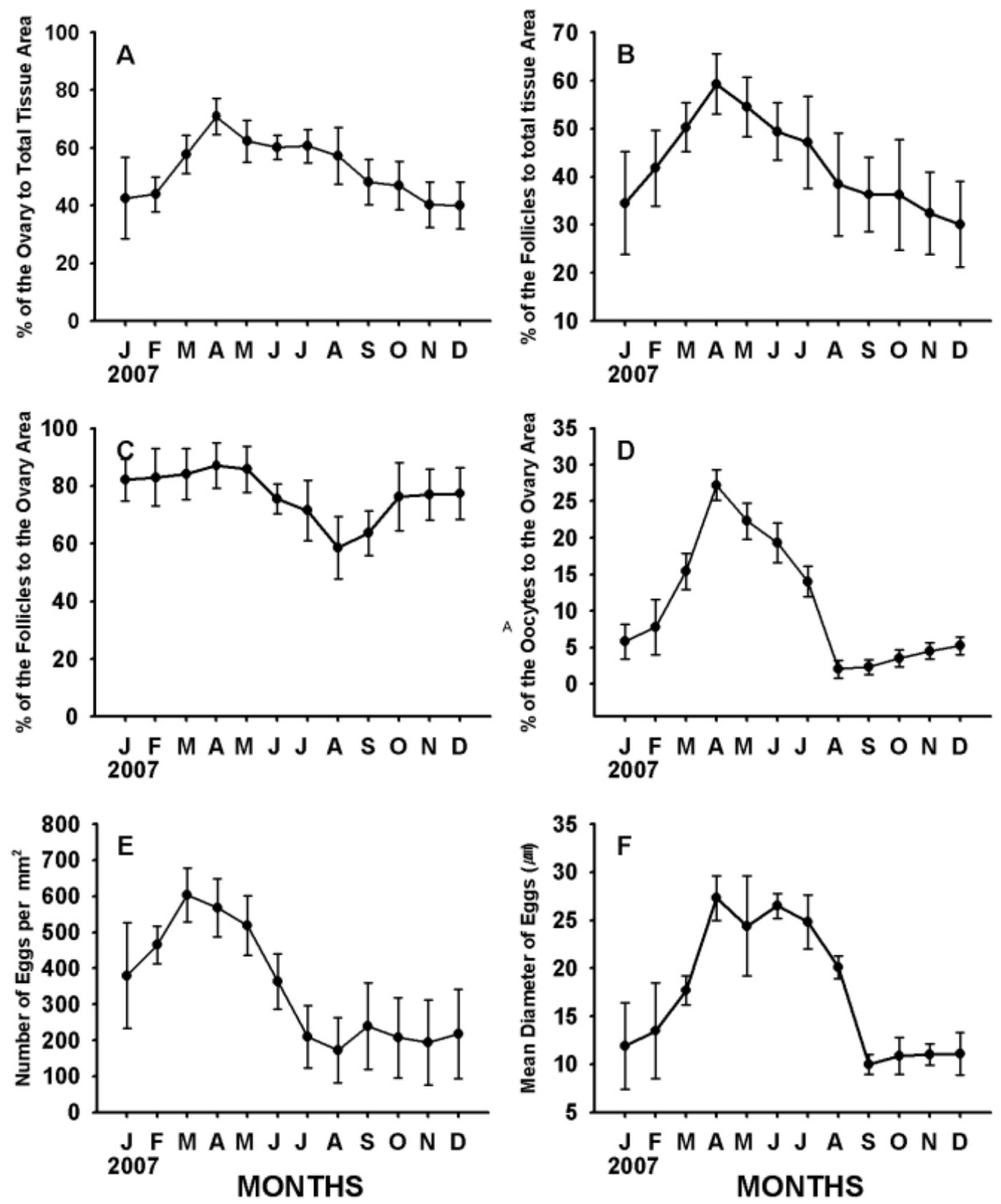

Fig. 2. Monthly changes in quantitative reproductive traits in female Protothaca (Notochione) jedoensis. A: Percent of the area occupied by the ovary to total tissue area. B: Percent of the area occupied by follicles to total tissue area. C: Percent of the area occupied by follicles to the ovary area. D: Percent of the area occupied by oocytes to the ovary area. E: Percent of mean oocyte number per $\mathrm{mm}^{2}$. F: percent of mean oocyte diameter.

months. from February-March (Turkey Test, $\mathrm{p}=$ 0.047).

As shown in Fig. 2C, monthly changes in the percent of field occupied by the follicle area to the ovarian tissue area showed similar patterns to the results mentioned above in Figs. 2A, B. The peak of the follicle area to the ovarian tissue area were found in April (87.1\%), and then gradually decreased from May (85.8\%) to July (71.5\%). From September to December, it fluctuated with lower value. The result of a one-way ANOVA during the period of January to December was 0.004. According to the results of 
multiple comparisons by Turkey Test, there were no significant differences in the data of two adjacent months. from January to December (Turkey Test, all data of two adjacent months, $\mathrm{p}>0.05$ ).

In Fig. 2D, monthly changes in the percent of field occupied by oocytes to ovarian tissue also showed a distinct seasonal pattern. Monthly changes in the portions (\%) of oocyte area to ovarian tissue area in females began to increase in February and reached a maximum in April (27.2\%), and then rapidly dropped from May (22.3\%) to July (14.0\%) when spawnig occurred. The result of a one-way ANOVA during the period of January to December was 0.001. According to the results of multiple comparisons by Turkey Test, there were significant differences in the data of two adjacent months. from March-April and July-August (Turkey Test, $\mathrm{p}=0.019, \quad 0.004$, respectively (Fig. 2D).

As shown in Fig. 2E, the number of the oocytes increased from February- March (464.9-603.2 eggs $\left.\mathrm{mm}^{-2}, \mathrm{p}=0.657\right)$ and April-May (519.2-567.1 eggs $\left.\cdot \mathrm{mm}^{-2}\right), \mathrm{p}=0.213$ ), and then decreased from June to July (210.6-364.0 eggs $\left.\cdot \mathrm{mm}^{-2}, \mathrm{p}=0.542\right)$ with slight fluctuations. The result of a one-way ANOVA during the period of January to December was 0.001.

Acoording to the results of multiple comparisons by Turkey Test, there were no significant differences in the data of two adjacent months. from January to December (Turkey Test, all data $p>0.05$. Therefore, the variations of the number of oocytes among individuals were greater than between variations of all combinations of adjacent months (t-test, $\alpha=$ 0.05 ), the differences of means of the number of oocytes between adjacent months were not statistically significant (Fig. 2E).

In Fig. 2F, the seasonal pattern was well reflected also in the mean diameter of oocytes. the mean oocyte diameter increased in February and reached a maximum in April, and then declined from May to September $(24.4 \mu \mathrm{m}$ to $10.0 \mu \mathrm{m}, \mathrm{p}=0.05)$.

The result of a one-way ANOVA during the period of January to December was 0.001. According to the results of multiple comparisons by Turkey Test, there were no significant differences in the data of two adjacent months. from January to June and October to December (Turkey Test, the data of two adjacent months, $p>0.05$ (Fig. 2F) except for July-August ( $=0.001)$ and August-September $(\mathrm{p}=0.007), \mathrm{p}<$ 0.05 , respectively. On the whole, there were good coincidences of patterns among the area of spermatogenic stages in male, the area of follicles, area of oocytes, and the mean diameter of oocytes in female.

\section{2) Testicular gametogenic cycle}

Male $\quad P . \quad(N)$ jedoensis showed a unimodal gametogenic cycle (Fig. 3). As shown in Fig. 3A, monthly changes in the percent of field occupied by the testis to total tissue in males began to increase in February and reached a maximum in April (75.0\%), and then decreased from May (69.3\%) to July (65.8\%) when spawning occurred. However, it showed somewhat irregular changes. From September to December, the testis area fluctuated within the range of $43 \%-50 \%$. The result of a one-way ANOVA during the period of January to December was 0.001 . Acoording to the results of multiple comparisons by Turkey Test, variations of the testis area among individuals were so high that there is significant differences during January and February ((Turkey Test, the data of two adjacent months, $\mathrm{p}<0.05$ ), however, there were no significant differences during February-March, March-April, April-May, May-June, June-July, July-August, August-September, September-October, October-November, and November December-September, September-October, October-November, and November-December $(\mathrm{p}=1.000$, $0.075,0.625,0.663,1.000,0.252,0.952,0.963,0.157$, and 0.080 , respectively). Therefore, there were no significant differences in the data of two adjacent months. from January to December (Turkey Test, all data of two adjacent months, $\mathrm{p}>0.05$ ).

Monthly changes in the percent of field occupied by spermatogenic stages to the testis began to increase in February and reached a maximum in April (55.0\%), and then decreased from May (53.2\%) to July (20.6\%) when spawnig occurred (Fig. 3B). Seasonal cycle was found evidently from the area of the spermatogenic stages. As shown in Fig. 3B, from January-April to 

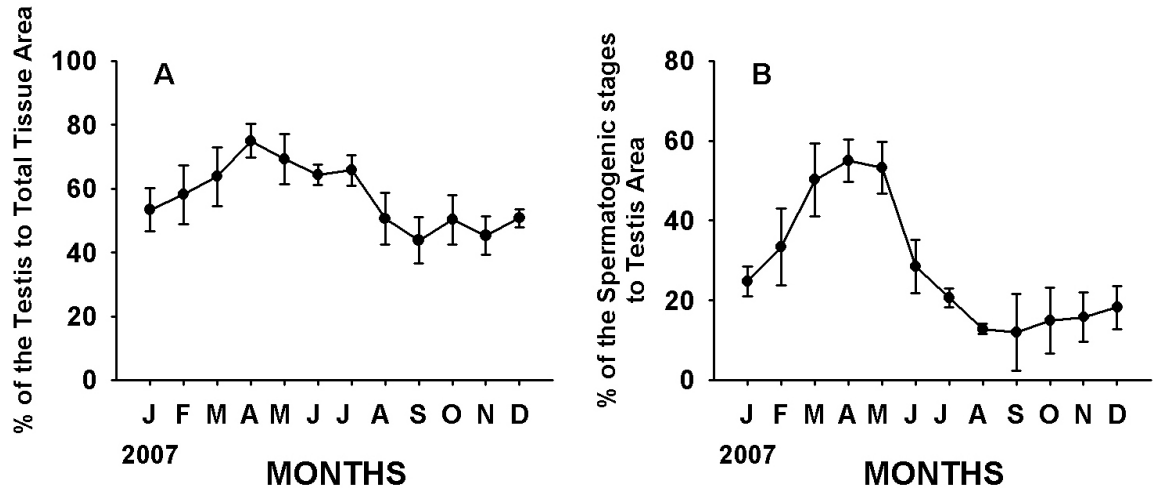

Fig. 3. Monthly changes in quantitative reproductive traits in male Protothaca (Notochione) jedoensis. A: Percent of area occupied by testis to total tissue area. B: Percent of area occupied by spermatogenic stages to testis area.

May-July, the testis area fluctuated within the range of $20-55 \%$, however, from Augusr to December, the testis area fluctuated within the range of $10-18 \%$. The result of a one-way ANOVA during the period of January to December was 0.001.

According to the results of multiple comparisons by Turkey Test, variations of the percent of field occupied by spermatogenic stages to the testis area among individuals were so high that there is significant differences during February-March ( $p=$ $0.001)$, May-June $(p=0.001)$, and July-August $(p=$ 0.006) ((Turkey Test, the data of two adjacent months, $\mathrm{p}<0.05$ ), however, there were no significant differences in most data of two adjacent months (Turkey Test, the data of two adjacent months, $p>0.05$ ) during January-February, March-April, April-May, June-July, August-September, September-October, October-November, and November December ( $\mathrm{p}=1.000,0.075,0.880,0.778$, 1.000 and 0.709 , respectively) (Fig. 3B).

\section{Sizes at sexual maturity by histological observations}

A total of 228 (111 females and 117) individuals of $P$. (N.) jedoensis were investigated histologically to determine the shell lengths of clams that reach maturation and participate in reproduction from April (maturation before spawning) to September (after spawning). As shown in Table 1, percentages of smaller female and male individuals ranging under $22.0 \mathrm{~mm}$ in shell length were $0 \%$, and those individuals were in the early active stage, which is characterized by a small number of oogonia in the follicle of the ovary, and the appearance of a small number of spermatogonia in the acini of the testis. Percentages of sexual maturities of female and male clams ranging from $25.2-30.0 \mathrm{~mm}$ shell length were $28.6 \%$ and $31.3 \%$, respectively, and those individuals were in the early active stage and late active stages. At this time, younger animals had a small number of oogonia and developing oocytes in the late active

Table 1. Shell lengths of sexual maturity and in female and male Protothaca (Notochione) jedoensis during the breeding season

\begin{tabular}{ccccc}
\hline \multirow{2}{*}{ Shell length $(\mathrm{mm})$} & \multicolumn{2}{c}{ Female } & \multicolumn{2}{c}{ Male } \\
\cline { 2 - 5 } & Number (ind.) & Mature (\%) & Number (ind.) & Mature (\%) \\
\hline $25.2-30.0$ & 14 & 28.6 & 16 & 31.3 \\
$30.1-35.0$ & 15 & 53.3 & 18 & 61.1 \\
$35.1-40.0$ & 18 & 72.2 & 17 & 88.2 \\
$40.1-45.0$ & 15 & 93.3 & 19 & 94.7 \\
$45.1-50.0$ & 17 & 100.0 & 18 & 100.0 \\
$50.1-55.0$ & 16 & 100.0 & 15 & 100.0 \\
$55.1-60.0$ & 13 & 100.0 & 12 & 100.0 \\
$60.1-64.7$ & 3 & 100.0 & 2 & 100.0 \\
\hline Total & 111 & & 117 & \\
\hline
\end{tabular}


stage in the follicles of the ovary, and a number of spermatocytes, spermatids, and a small number of spermatozoa appeared in acini of the testis. It is supposed that sexual sizes of most individuals can not be reached until July when spawning of a few mature individuals were completed. However, percentages of sexual maturities of female and male clams ranging from $30.1-35.0 \mathrm{~mm}$ in shell length were $53.3 \%$ and $61.1 \%$, but those individuals were in the early active, late active, ripe, and partially spawned stages during the breeding season. Percentages of sexual maturities of all individuals of shell length greater than $40.1 \mathrm{~mm}$ are $100 \%$, and those individuals were in the late, ripe, partially spawned, and spent/inactive stages. Therefore, it is assumed that most individuals can reach full maturity until July if they are larger 40.1 $\mathrm{mm}$ in shell length at that time. In this study, percentages of sexual maturities of female and male clams ranging from $30.1-35.0 \mathrm{~mm}$ were over $50.0 \%$. So, we can not understand accurate sizes at $50 \%$ sexual maturities of female and male individuals. Therefore, we have to calculate their accurate shell lengths at $50 \%$ of sexual maturities (biological minimum size) by quantitative analysis. Percentages were $100 \%$ for female and male clams over $40.1 \mathrm{~mm}$ length.

\section{Biological Minimum Size (Size at $\mathbf{5 0 \%}$ of Group Sexual Maturity $\left(\mathbf{R M}_{50}\right)$}

As shown in Figs. 4, 5, shell lengths of sexually mature The jedo venus clam (sizes at the rate $(50 \%)$ of group sexual maturity, $\mathrm{RM}_{50}$ ) that were fitted to an exponential equation were $32.01 \mathrm{~mm}$ in females (Fig. 4) and $30.58 \mathrm{~mm}$ in shell length in males (Fig. 5).

\section{DISCUSSION}

\section{Comparisons of the ovarian gametogenic cycle by qualitative and quatitative analyses}

To compare the results of the gametogenic cycle by qualitative and quantitative analyses of $P$. (N.) jedoensis in this study, we quoted the results on the reproductive cycle by qualitative analysis in female $P$. (N.) jedoensis already reported by Kim et al. (2003a). After studing in 1999, they reported that the reproductive cycle in female $P$. (N.) jedoensis in

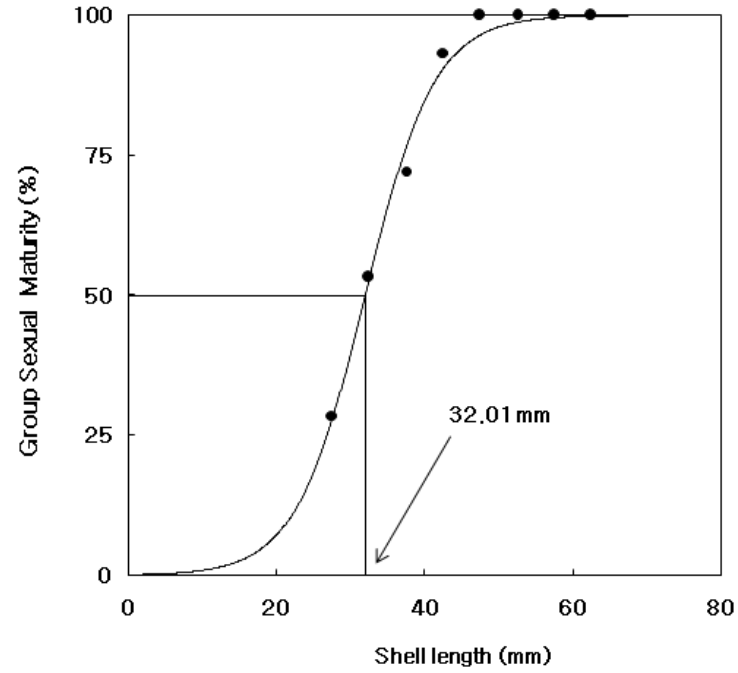

Fig. 4. Relationship between the rate of group sexual maturity $(\%)$ and shell length $(\mathrm{mm})$ in female Protothaca (Notochione) jedoensis.

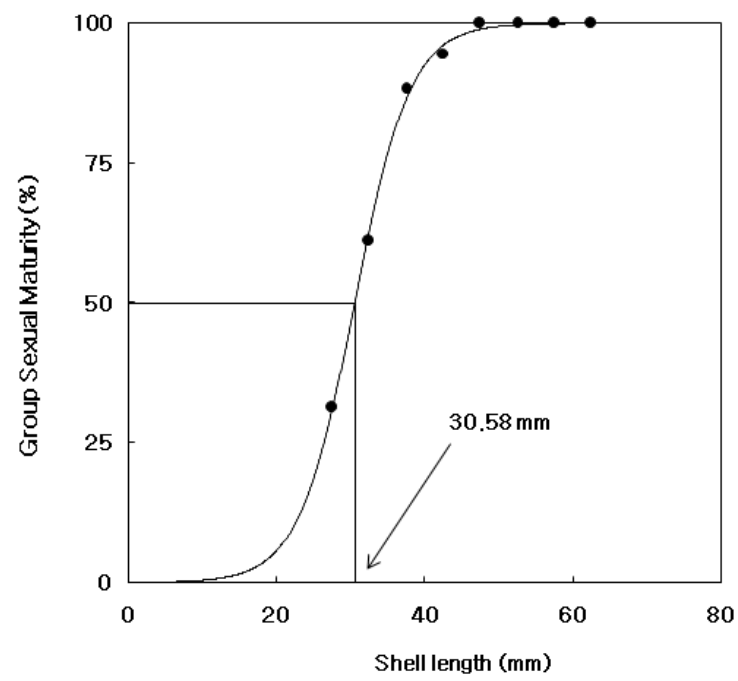

Fig. 5. Relationship between the rate of group sexual maturity $(\%)$ and shell length $(\mathrm{mm})$ in male Protothaca (Notochione) jedoensis.

Daecheon, Boryeong Coastal Waters, Korea by qualitative analysis (histological observation) could be classified into 5 successive stages: the early acive stage (December to March), late active stage (February to June), ripe stage (April to July), partially spawned stage (May to July), with a peak spawnig between June and July, and spent/inactive stage (July 
to January).

Although the collection date of the specimens and the number of individuals were not same each other, in general, the gonad index and condition index by month and the spawning season of the individuals by month were almost same.

In this study, according to the results of gametogenic cycle by quantitative statistical analysis, monthly changes in the percent of field occupied by the follicle area to the ovarian tissue area, and monthly changes in proportions (\%) of the oocyte areas to the ovary areas reached a maximum in April, and gradually decreased from May to July when spawning occurred, and the main spawning occurred between June and July. In particular, peak mature oocyte level occurred in April followed by a significant decrease from May to July which indicated spawning (the main spawning occurred between June and July). Therefore, monthly changes in the gametogenic cycle by qualitative and quantitative analyses showed similar patterns. However, there are slightly differences in the spawning seasons between the results of this study (2007) by qualitative analysis and of the previous study (2003) of the gonad index and condition index by qualitative analysis.

Commonly, monthly changes in the gonad index and condition index suggested the spawning seasons by indirect method. To compare some differences in the results of the spawning seasons between this study (during 2007) and previous study (in 2003), we quoted the data during the same period (in 1999) reported by Kim (2002) and Kim et al. (2003) to confirm the spawning season.

According to monthly changes in the gonad index, which is investigated from January to December in 1999 we quoted, Kim et al. (2003) reported that changes in the gonad index reachead a maximum in May and rapidly droped from June to December, 1999. And also Kim et al. (2003) reported that monthly changes in the condition index, that we quoted as a reference, reached a maximum in May and rapidly droped from June to December, 1999. Thus, from these two data, we can confirm that the spawning season of this species is from June to
August because of reaching in May and rapidly dropped from June to December (Kim et al., 2003a,b).

However, Kim et al. (2003a) reported that the spawning season is from May to July. Therefore, their reports have somewhat a little differences by month and year.

In females, monthly changes in the number of the oocytes per $\mathrm{mm}^{2}$, and mean diameter of the oocytes showed the same or similar patterns: the maximum in March-April, and then rapidly dropped from May to June which indicated spawning. Therefore, compared female gametogenic cycle by quantitative statistical analysis with those by qualitative histological analysis (Kim et al., 2000b; Chung et al., 2004), the results the gametogenic cycle studied by quantitative statistical analysis in this study coincided with gonadal maturation and the spawning season studied by qualitative histological analysis (Kim et al., 2000b; Chung et al., 2004). In females, spawning of this species was clarified from July to October by qualitative analysis (Kim et al., 2000b; Chung et al., 2004),

Therefore, in case of target orgarnism for aquaculture, it is assumed that the gametogenic cycle (reproductive cycle) should be investigated in detail by quallitative histological analysis and quantitative statictical anlysis because the reproductive cycle by the method of qualitative, histological analysis has many errors occurred by individual subjectivity.

\section{Number of the spawning seasons}

From the results of the number of spawning seasons investigated by quantitative statistical analysis using an Image Analyzer System, the gametogenic cycle in both sexes was clarified to be a unimodal gametogenic cycles showing a maximum maturity in May and one spawning season per year, from May to July with peak spawning between June and July.

Giese (1959) and Sastry (1979) reported that in general, latitudinal differences in timing of the reproductive cycles of marine molluscs. In particular, some authors (Ropes and Stickney, 1963; Brousseau, 1978; Heffernan et al., 1989a) reported that Mya 
arenaria and Mercennaria mercennaria in Bivalve mollusc exhibited a change from a unimodal to a bimodal cycle with decrease in latitude. However, another authors (Heffernan and Walker, 1989; Heffernan et al., 1989b) reported that several other bivalves (i.e, Geukensia demisa, Crassostrea virginica and Spisular solidissima similis) showed unimodal gametogenic cycle in the southeastern U.S. waters (Kanti et al., 1993). In this study, the gametogenic cycle in female and male $P$. (N.) jedoensis by quantitative statistical analysis showed a unimodal gametogenic cycle.

$P$. (N.) jedoensis showed a unimodal gametogenic cycle as found in other clams in Korean coasts. Quantitative results by image analyses of $P$. (N.) jedoensis showed the peaks of maturity in May-June (Figs. 1, 2). Compared to qualitative results (frequencies of gonadal phases) of other clams in previous works, the period of maturity of $P$. (N.) jedoensis quite similar to May-June of Ruditapes philippinarum (Chung et al., 1994), Mactra veneriformis (Chung and Ryou, 2000), and Meretrix lusoria (Chung, 2007), In this study, peaks of the oocyte area in females and the spermatogenic stages in males in April (Fig. 2D, 3B) implies the readiness of gonadal maturation. Spawning seemed to initiate in May by decrease of both the oocyte area and the area the spermatogenic stages. Significant decreases in the oocyte area and the area of the spermatogenic stages were found during May-July, indicating the spawning period. The spawning period of $P$. (N.) jedoensis was also similar to other clams mentioned above (June-September for $R$. philippinarum, $M$. veneriformis and $M$. lusoria, May-October for $S$. purpuratus).

\section{Size at sexual maturity}

The percentage of first sexual maturity of female and male clams ranging from 30.1 to $35.0 \mathrm{~mm}$ length were over $50 \%$, and this was $100 \%$ for clams over 45.1 $\mathrm{mm}$ length. According to the growth curves for the mean shell length fitted to von Bertalanffy's equation by Kim et al. (2003b), individuals ranging from 30.1 to $35.0 \mathrm{~mm}$ in shell length were considered to be two years old because Kim et al. (2003) reported that
30.58 and $32.01 \mathrm{~mm}$ in shell length were considered to be two years old. Therefore, we assume that both sexes of this population begin reproduction from two years of age.

\section{Biological minimum size (Size at $\mathbf{5 0 \%}$ of group sexual maturity)}

To clarify the biological minimum size, we should calculate shell lengths at $50 \%$ of sexual maturity to clarify acurate shell lengths which were fitted to an exponential equation by von Bertalanffy's equation already used by Kim et al (1986) in female and male clams. The biological minimum size (considering to $50 \%$ of group sexual maturity) in female and male clams by quantitative analysis of this species are $32.01 \mathrm{~mm}$ in shell length in females (Fig. 4), and $30.58 \mathrm{~mm}$ in males (Fig. 5), respectively. According to the results on the age and growth by Kim et al. (2003b), female and male clams ranging from 30.58 to $32.01 \mathrm{~mm}$ in shell length were considered to be two years old. In terms of natural resource management, the present study suggests that harvesting clams less than $30.6 \mathrm{~mm}$ in shell length $(<2$ years old $)$ can potentially lead to a drastic reduction in recruitment.

\section{ACKNOWLEDGEMENTS}

The authors are grateful to Dr. Je Chun Jun of West Sea Fisheries Research Institute, NFRDI, for helpful comments on the manuscript and surplying several data. This research was supported in part by the fund from the Research Projects (2011) of the Fisheries Science Institute, Kunsan National University.

\section{REFERENCES}

Brousseau, D.J. (1978) Spawniong cycle. fecundity and recruitment in a pupulation of soft-shell clam. Mya arenaria from Cape ann, Massachusetts. Fisheries Buletin. 76: 155-166.

Chung, E.Y, Ryou D.K, and Lee J.H. (1994) Gonadal development, age and growth of the shortnecked clam, Ruditapes philippinarum (Pelecypoda: Veneridae), on the coast of Kimje. Korean Journal of Malacology, 19: 38-54.

Chung, E.Y and Ryou D.K. (2000) Gametogenesis and sexual maturation of the surf clam, Mactra veneriformis on the west coast of Korea. 
Malacologia, 42: 149-163.

Chung, E.Y., Park, K.H., Kim, J.B. and Lee, C.H. (2004) Seasonal changes in biochemical components of the adductor muscle and visceral mass tissues in female Cyclina sinensis, in relation to gonad developmental phases. Korean Journal of Malacology, 20: 85-92.

Chung, E.Y. (2007) Oogenesis and sexual maturation in Meretrix lusoria (Roding 1978, Bivalvia: Veneridae) in western Korea. Journal of Shellfish Research, 26: 71-80.

Edwat, J.W. Carriker, M.R.,Villalaz, Z.R.,Gomez, J.A. and D'Crez, L. (1988) Gametogenic development of the venerid clam Protothaca asperirima in the Bay of Panama. Journal of Shellfish Research, 7: 118-126.

Era, A.M. (1995) Effects of tide and salinity on increment and line formation in the shells of the bivalve mollusk Protothaca staminea. Dissertation Abstracts International Part B: Science and Engineering, 46: 107-111.

Giese, A.C. 1959. Compartative Physiology: Annual reproductive cycles of marine invertebrates. Review of Physiology, 21: 547-576.

Harrington, R. (1987) Growth patterns within genus Protothaca (Bivalvia: Veneridae) from the Gulf of Alaska to Panama aleotemperatures, paleobiogeography and paleolatitudes. Dissertation Abstracts International Part B: Science and Engineering, 7: 249-256.

Heffernan, P.B., Walker, R.L. and Carr, J.L. (1989a) Gametogenic cycles of three bivalves in Wassaw Sound, Georgia I : Mercenaria mercenaria (Linnaeus, 1758). Journal of Shellfish Research, 8: 51-60.

Heffernan, P.B., Walker, R.L. and Carr, J.L. (1989b) Gametogenic cycles of three bivalves in Wassaw Sound, Georgia II: Crassostrea virginica (Gmelin, 1971). Journal of Shellfish Research, 8: 61-70.

Heffernan, P.B. and Walker, R.L. (1989) Gametogenic cycles of three bivalves in Sassaw Sound, Georgia III: Geukensia demissa (Dillwyn). Journal of Shellfish Research, 8: 327-334.

Holland, D.A. and Chew K.K. (1974). Reproductive cycle of the manila clam Washington. Proceedings of National Shellfish Research Association, 64: 53-58.

Kanti, A, Heffernan, PB, and Walker, R.L. (1993) Gametogenic cycle of the southern surfclam, Spisula solidissimasimilis (Say, 1822), from St. Catherine Sound, Georgia. Journal of Shellfish Research, 12 :
255-261.

Kim, J.R., Chung, E.Y., Choi, M.S. and Ryou, M.H. (1986) Environment in Busa Bay and Marine Resource Biological Studies. Bulletin of the Institute of Natural Sciences, Kunsan National University, I: 151-197.

Kim, Y.G., Chung, E.Y. and Kim, Y.H. (2000a) Studies on reproductive ecology and parasite of the venus clam, Cyclina sinensis on the west coast of Korea. 2. On the Metacercaria of Himasthia kussigi Yamaguchi, 1939 (Trematoda) found in the venus clam, Cyclina sinensis. Korean journal of Malacology, 16: 43-48.

Kim, Y.H., Chung, E.Y. and Kim, Y.K. (2000b) Reproductive ecology and parasite of the venus clam, Cyclina sinensis (Gmelin), on the west coast of Korea 1. Reproductive ecology. Korean Journal of Malacology, 16: 35-41.

Kim, J.H. (2002) Reproduction, age and growth of the jedo venus Protothaca jedoensis on Boryeong coastal waters of Korea. Kunsan National University, Ph.D. Thesis, $91 \mathrm{pp}$.

Kim, J.H., Chung, ,E.Y. and Kim, Y.H. (2003a) Sexual maturation and the sex ratio of the jedo venus, Protothaca jedoensis (Bivalvia: Veneridae). Korean Journal of Malacology, 19: 9-17.

Kim, J.H., Kim, J.S., Kim, Y.H. Chung, E.Y.and Ryu, D.K. (2003b) Age and growth of the jedo venus clam, Protothaca jedoensis on the west coast of Korea. Korean Journal of Malacolodgy, 19: 125-132.

Kwon, O..K, Park, G.M, and Lee, J.S. (1993) Coloured shells of Korea. Academy Publication Co. Seoul 288 pp.

Matos, E., Matos, P.,Casal, G. and Azev, C. (1997) Ultrastructure of the spermatozoon of Protothaca pectorina Lamarck (Mollusca: Vivalvia) of the North littoral Brazil. Review of Brazil Zoology, 14: 779-783.

Min, D.K., Lee, J.S, Ko, D.B, Je, J.G. (2004) Mollusks in Korea. Hanguel Graphics, Busan, Korea 566 pp.

Pizarro, J.F. and Cruz, R.A. (1987) Repreoductive cycle of the clam Prototac grata (Pelecypoda: Veneridae). Brenesia. San Joe, 27: 23-24.

Ropes, J.W. and Stickney, A..P. (1965) Reproductive cycle of Mya arenaria in New England. Bioogical Bulletin, 128: 315-327. 